\title{
A RECUSA E AS CRENÇAS: A DIMENSÃO NARCísICA DA NÃO ADMISSÃO DA CASTRAÇÃO
}

\section{Vanessa Chreim}

Pontifícia Universidade Católica de São Paulo

Elisa Maria de Ulhôa Cintra

Pontifícia Universidade Católica de São Paulo
Recebido em: 22/07/2020

$1^{\text {a }}$ revisão em: 31/10/2020

Aceito em: 20/11/2020

\section{RESUMO}

A partir da obra de Freud, trabalha-se a noção de Recusa (Verleugnung) como um mecanismo de defesa presente em todas as formas de subjetivação. A Recusa defende o narcisismo da ameaça de castração, que não se restringe à perda do genital, mas evoca diversas outras feridas narcísicas. Este artigo analisa as transmissões familiares inconscientes e sua relação com a simultânea admissão e não admissão da castração. A fantasia infantil da mãe fálica evidencia a ação da Recusa na manutenção das crenças irracionais e seus efeitos sobre o senso de realidade. Este trabalho aborda as manifestações da Recusa no cotidiano e nos adoecimentos psíquicos e comprova a importância do conceito na ampliação da teoria e da clínica psicanalítica.

Palavras-chave: recusa (Verleugnung); crenças irracionais; castração; narcisismo; clínica psicanalítica. 


\title{
DENIAL AND BELIEFS: THE NARCISSISTIC DIMENSION OF THE NON-ADMISSION OF CASTRATION
}

\begin{abstract}
Based on Freud's work, this paper focuses on the notion of denial (Verleugnung) as a defense mechanism present in all forms of subjectivity. Denial defends narcissism against castration threat, which is not restricted to the loss of genitals, but evokes several other narcissistic wounds. This article analyzes the unconscious family transmissions and their relationship with the simultaneous admission and nonadmission of castration. The phallic mother childish fantasy shows denial's action in maintaining irrational beliefs and their effects on the sense of reality. This paper explores denial's manifestation in everyday life and in psychic illnesses, and attests the importance of that concept in the expansion of psychoanalytic theory and clinic.
\end{abstract}

Keywords: denial; irrational beliefs; castration; narcissism; psychoanalytic clinic. 


\section{LA NEGACIÓN Y LAS CREENCIAS: LA DIMENSIÓN NARCISICA DE LA NO ADMISIÓN DE LA CASTRACIÓN}

\section{RESUMEN}

Basándose en la obra de Freud, se trabaja la noción de negación (Verleugnung) como mecanismo de defensa presente en todas las formas de subjetividad. La negación defiende el narcisismo contra la amenaza de castración, que no se limita a la pérdida del genital, sino que evoca varias otras heridas narcisistas. Este articulo analiza las transmisiones familiares inconscientes y su relación con la simultánea admisión y no admisión de la castración. La fantasía infantil de la madre fálica evidencia la acción de la negación en la manutención de creencias irracionales y sus efectos sobre el sentido de la realidad. Este trabajo explora las manifestaciones de la negación en la vida diaria y en enfermedades psíquicas, y comprueba la importancia de este concepto en la expansión de la teoría y de la clínica psicoanalítica.

Palabras clave: negación; creencias irracionales; castración; narcisismo; clínica psicoanalítica. 


\section{INTRODUÇÃO}

Enquanto mecanismo de defesa, por vezes a noção de Recusa é considerada uma contribuição teórica de incerta aplicabilidade, mas em nossa opinião trata-se de uma construção fundamental e de um fenômeno que se manifesta em todas as formas de subjetivação, como afirmou Freud em Compêndio de Psicanálise (1940/2018). A estreita relação entre Recusa e perversão já é amplamente difundida na bibliografia psicanalítica, no entanto, a dimensão das crenças descortina outra forma de manifestação da Recusa, presente em todas as organizações psíquicas. Portanto, a contribuição singular deste artigo é indicar que a Recusa é um fenômeno muito mais frequente e relevante do que se supõe, tanto na teoria como na clínica psicanalítica.

Por meio do tema das crenças, abordaremos a especificidade da Recusa como mecanismo de defesa em sua função protetora, mas que também pode levar a adoecimentos psíquicos. Um dos efeitos da Recusa é a paralisação dos processos psíquicos, em que a fixação pode fazer com que as fantasias deixem de ser provisórias interpretações sobre o mundo e se tornem crenças irracionais, intransigentes e concretas. Por um lado, nem todas as crenças são patológicas, no entanto, todas comportam algum nível de Recusa.

A Recusa e as crenças protegem o narcisismo contra tudo o que o ameace, mas este mecanismo de defesa pode levar ao sofrimento psíquico ao perturbar o senso de realidade e enrijecer o psiquismo. As transmissões inconscientes que fundam o psiquismo atravessam a herança narcísica e os modos de relação com o mundo, e podem estar ligadas à etiologia da Recusa e à decorrente cisão do Eu. Neste sentido, abordamos a Recusa do ponto de vista intersubjetivo.

As alterações e deformações do Eu foram alvo de diversos textos de Freud: Observações adicionais sobre as neuropsicoses de defesa (Freud, 1896/2006) e Análise terminável e interminável (Freud, 1937/2018). No texto Neurose e psicose, (Freud, 1924/2011) o autor também indaga quais são as circunstâncias em que o Eu pode vir a se deformar, comparando e discernindo o processo de defesa da neurose e da psicose. Tais hipóteses são retomadas em $A$ perda da realidade na neurose e na psicose (Freud, 1924/2011), porém, especialmente a partir do estudo do fetichismo, Freud (1927/2014) identifica um modo de funcionamento mental que serve como modelo para compreender a Recusa: o que caracteriza esta defesa é a formação de duas correntes psíquicas opostas e simultâneas, que levam à cisão do Eu (Freud, 1940/2018). Assim, nos últimos textos da obra de Freud, a Recusa envolve a questão da relação com a realidade em todas as organizações psíquicas.

Embora todo processo de defesa promova alguma perturbação da relação do sujeito com a realidade, a Recusa distingue-se da repressão, uma vez que é mais radical e mutilante. A repressão se organiza a partir do conflito entre instâncias 
psíquicas, do qual resulta o sintoma neurótico, representando simbolicamente a oposição entre desejo e censura. Entretanto, na Recusa a dinâmica psíquica é outra: o conflito é intrainstância, ou seja, o Eu se torna o campo de batalha entre as forças psíquicas em questão, que se opõem quanto a admitir e não admitir a realidade. Tal distinção tópica é importante, pois a cisão do Eu decorrente da Recusa implica uma alteração estrutural que perturba o funcionamento psíquico em termos econômicos e dinâmicos. Faz-se necessária uma ampliação da escuta do psicanalista para além do modelo clínico da repressão.

A fim de conferir atualidade ao conceito, acompanhamos a evolução e a transformação da noção de Recusa ao longo da obra de Freud e estabelecemos um diálogo com autores contemporâneos. Alinhamo-nos à concepção de que a Psicanálise contemporânea nasce de um pensamento transmatricial (Figueiredo \& Coelho Junior, 2018), em que as leituras de diferentes linhas teóricas se suplementam, apesar de se apoiarem em diferentes pressupostos. Ainda que não possamos abarcar a totalidade do fenômeno, este método possibilita abordar a complexidade da Recusa de forma mais ampla, articulando uma perspectiva intersubjetiva e intrapsíquica. Como afirma Ferraz: "A recusa comporta, portanto, vários objetos, o que lhe confere faces variadas que, todavia, não lhe retiram a unidade conceitual" (2010, p. 60).

O conceito de Recusa advém do termo em alemão Verleugnung e suas variações, porém, consideramos que a falta de padronização na tradução contribui para a imprecisão da importância teórica e clínica em torno do tema. Por exemplo, a tradução como negação (e suas variações "denegação" ou "renegação") levou a uma confusão teórica importante. Segundo Freud (1925/2011), a negação (Verneinung) é um processo psíquico envolvido no estabelecimento da função de julgamento e é a marca da ação da repressão. Por sua vez, a Recusa (Verleugnung) tem o efeito contrário, uma vez que perturba o exercício do julgamento e suspende o teste de realidade, como veremos adiante. Portanto, optamos por traduzir o termo Verleugnung como Recusa e o grafamos com letra maiúscula para conferirIhe o estatuto de um conceito - e não, de um verbo. Por sua vez, em seus textos mais maduros sobre o tema, Freud também dá destaque ao conceito escrevendo die Verleugnung, "a Recusa", tratando o termo como um substantivo.

\section{RAÍZES FREUDIANAS DA RECUSA}

Autor de Figuras da Recusa, Penot (1992) estabelece três momentos da evolução conceitual da noção de Recusa na obra de Freud. De início, Freud não usa um termo específico, mas descreve o movimento defensivo da criança durante as suas investigações sobre a sexualidade, como observamos em Sobre as teorias sexuais das crianças (Freud, 1908/2015) e em Análise de uma fobia em um menino de cinco anos (Freud, 1909/2015). A partir de Conferências introdutórias à psicanálise (Freud, 1916-1917/2014), o termo Verleugnung passa a ser usado com frequência pelo autor para se referir ao ato psíquico de tratar uma percepção como impensável. 
Nos textos A organização genital infantil (Freud, 1923/2011) e Algumas consequências psíquicas da diferença anatômica entre os sexos (Freud, 1925/2011), que abordam os meandros da sexualidade infantil e das questões fálicas, as variações do termo Verleugnung são empregadas para referir-se à reação normal diante da descoberta da diferença anatômica entre os sexos. Em O problema econômico do masoquismo (Freud, 1924/2011), o termo reaparece neste contexto infantil, mas ligado à noção de masoquismo erógeno. Finalmente, a partir de 1925, o autor passa a escrever die Verleugnung como um substantivo, elevando a Recusa à categoria de conceito. Isto se nota especialmente nos textos $O$ fetichismo (Freud, 1927/2014), Compêndio de psicanálise (Freud, 1940/2018) e A cisão do Eu no processo de defesa (Freud, 1940/2018), os quais abordam aspectos patológicos de tal mecanismo defensivo, estendendo-o a outros quadros clínicos além do fetichismo.

A noção de Verleugnung está enraizada no contexto da descoberta infantil da diferença anatômica entre os sexos - mais precisamente, a reação do menino diante do impacto da visão da ausência de pênis na mulher. Sob influência da teoria sexual infantil do primado do falo, o menino não interpreta que está diante da presença de algo novo e diferente, mas deduz que havia algo ali que foi retirado. A conclusão é de que as meninas foram punidas por meio da castração, o que desperta no menino o medo de vir a ser castigado também. É isso o que, na obra de Freud, confere o caráter potencialmente traumático à descoberta da ausência de pênis nas mulheres. Neste contexto, a Recusa intercede contra este horror gerado pela fantasia infantil.

Vemos assim como a fantasia de castração está diretamente ligada à fantasia do primado do falo (Laplanche \& Pontalis, 2001), ou seja, à crença de que todos possuem um pênis. $A$ interpretação da criança sobre sua experiência se dá sob a ótica desta crença que não se transformou, o que a leva a conclusões inadmissíveis quanto à castração. Porém, em vez de promover a revisão da teoria sexual infantil, a Recusa gera duas realidades psíquicas antagônicas e simultâneas, uma que admite e outra que não admite a castração - sendo está a particularidade desse mecanismo de defesa.

Nesse processo, a fantasia de castração é produzida, mas uma das correntes psíquicas recua horrorizada diante de suas deduções e se fixa no momento prétraumático, impedindo o processamento das consequências psíquicas da descoberta. Mannoni (1969/1991) nos permite compreender esta dupla atitude ao cunhar o jargão da Recusa: "eu sei, mas mesmo assim". O "mesmo assim" expressa a sobrevivência da crença, apesar do que se apresenta na realidade.

Mas o que significa admitir a castração? Segundo Laplanche e Pontalis (2001), este fenômeno não diz respeito à realidade material, já que a castração é uma fantasia, uma vez que à mulher não falta um genital. Portanto, é importante enfatizar que a 
Recusa se refere à não admissão da realidade psíquica, ou seja, atua sobre o impacto afetivo de uma experiência.

Apoiando-nos em Freud, compreendemos que a castração se refere a uma dimensão inerente à condição humana em seu aspecto de incompletude. Essa condição de ter que se confrontar com a falta, vulnerabilidade e insatisfação se expressa no movimento sempre oscilante de presença e ausência do seio, da mãe, do pênis e de outros objetos. Em A organização genital infantil, Freud (1923/2011) escreve:

Já foi corretamente assinalado que a criança adquire a ideia de um dano narcísico por perda corporal ao perder o seio materno após mamar, ao depositar cotidianamente as fezes e mesmo ao separar-se do ventre da mãe no nascimento. Mas só devemos falar de um complexo da castração quando tal ideia de perda ficou ligada ao genital (p. 173).

Assim, podemos reservar o termo complexo de castração para as questões psíquicas envolvendo a fase fálica e a sexualidade infantil genital, mas considerar que as diferentes facetas da castração estão presentes desde o início da vida. Desta forma, a castração se refere a tudo que ameaça de alguma forma o narcisismo e sua pretensa integridade, noção presente em Introdução ao narcisismo (Freud, 1914/2010). Compreendemos, portanto, que a Recusa não atua apenas na fase fálica, pelo contrário, defendemos que se trata de um processo de defesa que opera contra outras angústias, entre elas, a angústia de separação. Do mesmo modo, concebemos o fetichismo como um modelo de funcionamento psíquico que não se restringe às perversões sexuais ${ }^{1}$. Embora Freud tenha dado ênfase à anatomia no que diz respeito ao complexo de castração e ao complexo de Édipo feminino e masculino, a Psicanálise contemporânea ampliou o alcance destes conceitos, ultrapassando a concretude do pênis-falo ${ }^{2}$. Esta perspectiva envolve uma noção simbólica de falo, como um objeto ou um lugar imaginário referido à perfeição do narcisismo.

Jean Clavreul (1990) oferece um olhar renovado à cena freudiana da descoberta da diferença anatômica entre os sexos, o que nos permite interpretá-la no sentido metafórico. $\mathrm{O}$ autor destaca as consequências psíquicas que dizem respeito à mudança de posição subjetiva da criança nesta passagem emblemática. Nesse contexto, a descoberta da diferença anatômica entre os sexos descortina para a criança diversos aspectos da castração e Ihe demanda admiti-las e elaborá-las emocionalmente, o que implica uma série de feridas narcísicas.

Segundo Clavreul (1990), a descoberta da diferença entre os sexos coloca a criança diante de uma encruzilhada, uma vez que refuta suas convicções anteriores. Descobre-se, então, que o saber é sempre transitório, já que a posição subjetiva da 
criança, anterior a esta experiência, repousava em um saber errôneo: a fantasia do primado do falo. Aquele que admite a castração tem que rever suas teorias sexuais e abarcar a possibilidade de "não saber". Somos levados à compreensão de que o saber é algo sempre a ser reformulado e jamais é absoluto. Na contramão deste processo, a Recusa transforma as fantasias em crenças, de modo que elas deixam de ser provisórias e permeáveis, e não aceitam ser reformuladas pelas experiências emocionais vividas. Deste modo, a Recusa impede a construção de novos sentidos, o que promove um enrijecimento do psiquismo.

Uma destas crenças que custa a ceder é a da mãe fálica, ou seja, a crença na mãe onisciente e onipotente. Nesta medida, admitir a castração materna implica reconhecer que sua mãe não é completa e perfeita, ou seja, ela não tem infinitas capacidades de reparação e não pode garantir segurança e satisfação plenas. Contra estas terríveis ameaças é que a Recusa se interpõe.

Entretanto, é a dimensão desejante que poderá transformar a fantasia de castração e tornará possível a simbolização e elaboração das questões fálicas. É a relação do casal parental que permite à criança interpretar que a vagina não é a falta de pênis, mas a presença de algo diferente, que causa o desejo do pai. A novidade aqui é que a falta e a diferença se tornam motores do desejo: o que suaviza a perda da ilusão de completude narcísica é a possibilidade de encontrar diversos objetos de prazer.

Ao se dar conta de que não era o único objeto de desejo da mãe, a criança experimenta a perda desta ilusão idílica onde ela e sua mãe se completam, e se defronta com a alteridade presente em todos os relacionamentos, nos quais nunca sabemos o que somos para o outro. Nesse processo, a criança se dá conta do desejo que a habita e então descobre que não sabe tudo sobre si mesma. Assim, compreendemos que admitir a existência do inconsciente é também uma forma de admitir a castração e de reconhecer a alteridade, como o outro de si mesmo, sobre o qual o sujeito tem pistas, mas não tem controle.

Esta perspectiva desenha um amplo leque de feridas narcísicas como consequências psíquicas da descoberta da diferença anatômica entre os sexos. Elas promovem uma báscula entre o tempo da suposta integridade narcísica e o tempo do reconhecimento da própria incompletude e vulnerabilidade. Ao preservar a crença na mãe fálica, a Recusa procura restaurar a ilusão de estarmos sempre protegidos narcisicamente em termos de perda de amor e da ameaça da morte. Como afirma Aulagnier (2003), esta dimensão fundamental da Recusa está presente em todos nós.

\section{NARCISISMO: ADMISSÃO E NÃO ADMISSÃO DA CASTRAÇÃOO}

Vimos que admitir a castração provoca feridas narcísicas difíceis de serem superadas. Indagamos: o que favorece a admissão da castração? O que favorece a 
instalação da Recusa? Veremos que é necessário que haja suporte narcísico para que a castração não se torne inadmissível. O narcisismo, em todas as suas facetas, envolve um campo de ilusão que alude a promessas de completude e responde ao anseio de que nunca mais haja o encontro com a castração. Pinheiro (1999) afirma que a castração é somente admitida entre aspas, ou seja, desde que possa ser nutrida a expectativa de retornar a um estado de plenitude. Ela afirma:

[...] essa temporalidade que traz embutida a finitude, a impotência, está no duro pacote da castração, mas é aceita sob a condição de que o passado seja de plenitudes e no futuro haja a segurança da "felicidade" (Pinheiro, 1999, p. 32).

Nesta medida, a admissão da castração não pode envolver apenas perda, mas deve engendrar um movimento do sujeito para recuperar seus investimentos libidinais. Portanto, a castração só pode ser admitida se não comprometer a articulação de um campo de desejo e de ilusão, em que se pode fazer de conta ou almejar a não castração. Neste contexto, a crença em uma promessa utópica pode não ser patológica: expressa uma almejada segurança narcísica que leva o sujeito a construir um lugar para si no mundo.

Este campo de ilusão é criado numa relação intersubjetiva entre pais e filhos, numa ficção em que a criança vem como consolo para a castração dos genitores. Esta expectativa permite o voto narcísico no filho ansiado e a prospecção de seu futuro brilhante. Sobre a criança, Freud afirma:

Ela deve concretizar os sonhos não realizados de seus pais, tornar-se um grande homem ou herói no lugar do pai, ou desposar um príncipe, como tardia compensação para a mãe. No ponto mais delicado do sistema narcísico, a imortalidade do Eu, tão duramente acossada pela realidade, a segurança é obtida refugiando-se na criança. $O$ amor dos pais, comovente e no fundo tão infantil, não é outra coisa senão o narcisismo dos pais renascido, que na sua transformação em amor objetal revela inconfundivelmente a sua natureza de outrora (1914/2010, p. 37).

Concluímos que existe uma promessa sedutora no narcisismo de que, se o sujeito satisfizer as expectativas que lhe foram endereçadas, ele voltará a ser amado como quando era um bebê. Neste sentido, há sempre uma dimensão do narcisismo que aspira à não castração, ao retorno da plenitude, e tem traços incestuosos.

Esta dimensão de pertencimento narcísico pode oferecer uma pretensa garantia de amor. "Eu sei que não sou tudo para o outro, que as relações envolvem decepções e desamor, mas, mesmo assim, acredito que se eu satisfizer as expectativas do outro estarei assegurado de que ele não me abandonará". Neste 
sentido, o que está em jogo na contestação das crenças é abrir mão das garantias ilusórias que elas oferecem como proteção, inclusive quanto ao desamparo afetivo.

De um lado, os desejos grandiosos dos pais projetados nos filhos são necessários para a constituição do psiquismo. Eles apontam na direção de um vir-a-ser, modelam a construção de um ideal a ser alcançado e mobilizam a preservação de uma imagem de si aos olhos dos outros. Entretanto, é preciso que o sujeito possa se distinguir dos pais para ir em busca de seus próprios desejos.

\section{AS CRENÇAS PROTETORAS}

Ainda que Freud não tenha se dedicado a discutir a metapsicologia das crenças, podemos nos apoiar em Mannoni (1969/1991) para abordar a relação entre este fenômeno e a Recusa. Segundo este autor, o tema das crenças atravessa a obra freudiana sempre ligada ao termo Verleugnung. Assim, considera que a crença na mãe fálica, preservada pela Recusa, é o protótipo a partir do qual derivam todas as outras crenças, inclusive nas neuroses. Em seu texto Eu sei, mas mesmo assim, Mannoni nos oferece diversos exemplos de crenças, como o mito do Papai Noel e outras tradições familiares.

Abordar a Recusa por meio das crenças oferece-nos uma visão mais ampla de como este mecanismo de defesa se manifesta em diversos quadros clínicos e mesmo na vida cotidiana. Evidentemente, há diferenças entre crenças derivadas do narcisismo primário, que são expressão de um funcionamento psíquico mais arcaico, e outras que alcançaram outro nível de simbolização e estão ligadas ao narcisismo secundário. Entretanto, em todas elas opera este movimento defensivo sustentado pela Recusa, ainda que apareça com diferentes roupagens, inclusive, na figura do pai totêmico, que frequentemente atravessa as crenças religiosas.

As crenças têm sempre a função de preservar o narcisismo de tudo que pode ameaçá-lo e sobrevivem para além da infância, especialmente diante da faceta da castração que mais nos ameaça: o desamparo afetivo, a nossa finitude e fragilidade. Prometem curar e eliminar as feridas narcísicas do passado, indenizar-nos das perdas e oferecem uma ilusória garantia de um futuro sem sofrimento.

Em situações traumáticas, quando nos vemos expostos a grandes desamparos e incertezas, as crenças geram um alívio temporário do sofrimento que a realidade e as frustrações nos impõem. Podem oferecer um conforto, da mesma forma que a ideia de uma mãe fálica cria a sensação de se estar protegido dos males do mundo. Assim, as crenças têm a função de sustentar o senso de existência, que é muito importante para atravessar situações intensamente perturbadoras. Sabemos que a vida não é feita de certezas, mas nos reasseguramos ao acreditar que "vai dar tudo certo". 
Na vida adulta, há diversas experiências que permitem notar a sobrevivência da crença no falo materno: são as superstições, o horóscopo e as coincidências, a telepatia, o xamanismo e até o prazer de ser bem enganado por um ilusionista.

Todas estas crenças são formas de almejar a perfeição e proteção narcísicas e de se defender da castração. Mannoni (1969/1991) compreende que, ao contar histórias míticas a uma criança, o adulto a coloca no lugar do crédulo, ou seja, no lugar daquela que não sabe sobre os segredos da vida e por isso acredita no que Ihe dizem. A história da cegonha ou da fada dos dentes visa a prolongar a inocência infantil, adiando a tarefa de lidar com a sexualidade e com as perdas. Nesse sentido, a criança se torna a depositária das crenças, como se o adulto não admitisse a sua própria condição de crente, mas indiretamente expressasse sua nostalgia de um tempo de ignorância sobre a castração.

Na obra de Freud, o tema das crenças lança luz sobre a relação com a realidade no texto Das Unheimliche (Freud, 1919/2010), em que o autor aborda uma série de experiências nas quais o senso de realidade parece vacilar. O termo em alemão Unheimliche já foi traduzido como "inquietante", "estranho familiar" ou, ainda, "infamiliar", na tentativa de apreender este sentimento do encontro com algo que parece muito estrangeiro e ao mesmo tempo muito conhecido. Enquanto nos oferece ricos exemplos cotidianos e literários em que é produzida a sensação de Unheimliche, Freud constrói uma série de hipóteses sobre as condições que criam esta sensação.

O autor não estabelece uma relação entre Unheimliche e Recusa, mas interroga se o retorno do recalcado é condição suficiente para provocar a vivência de Unheimliche. Conclui que tal sentimento é menos provocado pelo conteúdo do recalcado e mais pelo fato de que perturba o senso de realidade. Segundo Freud, "[...] o efeito do inquietante é fácil e frequentemente atingido quando a fronteira entre fantasia e realidade é apagada, quando nos vem ao encontro algo real que até então víamos como fantástico [...]" (1919/2010, p. 364).

Eis aqui outra diferença entre a negação (Verneinung) e a Recusa (Verleugnung): Freud (1919/2010) distingue o retorno do recalcado e o retorno das antigas convicções abandonadas, que voltam a ter um efeito de assombro no sujeito. A negação (1925/2011) se refere a uma ocasião em que o paciente não aceita que um conteúdo inconsciente que emergiu corresponda a seu desejo. Já a não admissão que está implícita na Recusa põe em jogo a validade da crença na realidade compartilhada. Propomos a seguinte distinção: o retorno do recalcado se expressa por meio da negação, enquanto o retorno do que foi alvo da Recusa se dá pela sensação de Unheimliche, a partir da reafirmação de crenças outrora superadas. Freud afirma:

Hoje não mais acreditamos neles, superamos tais formas de pensamento, mas não nos sentimos inteiramente seguros dessas 
novas convicções, as velhas ainda subsistem dentro de nós, à espreita de confirmação. Quando acontece algo em nossa vida que parece trazer alguma confirmação às velhas convicções abandonadas, temos a sensação do inquietante, que pode ser complementada pelo seguinte julgamento "Então é verdade que podemos matar uma outra pessoa com o simples desejo, que os mortos continuam a viver e aparecem no local de suas atividades anteriores!", e assim por diante (1919/2010, p. 369).

Assim, vemos claramente como Freud estabelece uma relação entre Unheimliche e crenças, embora nada afirme sobre a Recusa neste texto de 1919. Mas, segundo Mannoni, estas crenças e convicções persistentes que não cedem, mesmo diante da realidade, são sustentadas pela Recusa:

Em análise, vemos frequentemente reações ou efeitos inesperados revelarem crenças irracionais, "superstições", de que o sujeito não tem consciência, mas que não estão recalcados; não podemos torná-las manifestas triunfando sobre uma resistência, elas são, antes, inconsistentes, fugidias, inacessíveis [...] (1969/1991, p. 195).

A experiência de Unheimliche remete aos aspectos em nós que são como almas penadas ou mortos-vivos, como se de repente nossas fantasias assassinas, nossos anseios onipotentes e tudo aquilo que habita nosso imaginário pudesse se concretizar. Freud (1919/2010) destaca que as convicções primitivas e as crenças estão enraizadas nos complexos infantis e em diversos aspectos do narcisismo primário, como o animismo e as formas de pensar primitivas, que reaparecem nas experiências de Unheimliche. Se resgatarmos a ideia de um naufrágio ${ }^{3}$ do complexo de Édipo, podemos imaginar quão assombroso é quando aquilo que supúnhamos estar no fundo do mar de repente emerge e passa a navegar em altomar como um navio fantasma. Talvez seja por isso que vejamos tão frequentemente a figura dos zumbis na clínica com crianças.

As crenças e tradições que circulam no seio familiar oferecem suporte para atravessar as adversidades de um contexto ameaçador, na medida em que contêm saberes sobre o enfrentamento de traumas. Deste modo, esta transmissão que conecta o coletivo ao singular pode favorecer o processo de elaboração e representação, a partir da identificação com um modelo, o que também gera um senso de pertencimento e segurança. Neste sentido, as crenças podem ser antitraumáticas. No entanto, estas mensagens também podem ser formadas por enunciados muito inflexíveis e severos, como a célebre recomendação de que não se deve mostrar fraqueza e vulnerabilidade. Em alguns contextos, esta atitude é útil e protetora, entretanto, se for tomada como regra para a vida toda, esta crença pode levar a uma dissociação em relação aos próprios sentimentos. Vemos então como as crenças irracionais e incontestáveis, sustentadas pela Recusa, podem levar à não admissão da realidade psíquica. 


\section{AS CRENÇAS APRISIONADORAS}

Até então, abordamos aspectos das crenças em sua função defensiva ante o duro pacote da castração, sustentando ilusões que oferecem alívio e protegem o narcisismo. Mas, ao abordarmos o tema da Unheimliche como uma experiência que faz balançar o senso de realidade, aproximamo-nos de um aspecto da Recusa que diz respeito à não admissão da realidade psíquica. Portanto, passamos a nos embrenhar pelo campo do sofrimento e do adoecimento psíquico.

Penot (1992) compreende que a vivência de Unheimliche pode ser considerada como o primeiro sinal clínico da Recusa, que se manifesta como a terrível sensação de irrealidade. Quando ressurge uma crença que põe em xeque suas outras formas de interpretar o mundo, o sujeito não sabe mais em qual das duas versões de realidade ele deve acreditar. Trata-se de uma crença que, mesmo contestada pela realidade, persiste ecoando com força no psiquismo.

Este é um efeito da atitude dividida da Recusa, em que as duas correntes psíquicas antagônicas se tratam como externas, no sentido de que o mundo interno e o exterior se confundem, e não se pode discriminar com clareza o que é fantasioso e o que é parte da realidade compartilhada. Neste contexto, o teste de realidade não funciona mais. Este vacilar do senso de realidade pode causar um importante sofrimento psíquico na vivência de Unheimliche, em que o sujeito fica dividido entre dar crédito a novas conclusões emocionais ou a crenças e antigos enunciados sobre si mesmo.

A perspectiva de Penot (1992) nos revela que um dos efeitos da Recusa é o de desapropriar o paciente de suas próprias experiências emocionais, pois são constantemente desmentidas, invalidadas ou postas em dúvida por crenças irracionais que persistem e que não se deixam questionar. Tal como uma voz interna que diz ao sujeito que aquilo que ele sente e pensa é irreal, o que o leva a duvidar de suas próprias percepções a respeito do que vivencia.

Este autor nos propõe uma perspectiva intersubjetiva a respeito da etiologia da Recusa e das crenças aprisionadoras, relacionando-as com as transmissões familiares que permeiam e constituem o campo do narcisismo. Penot destaca que a relação que construímos com a realidade, com nosso próprio corpo e com o outro é atravessada pela especularidade. A constituição de nossa própria identidade é atravessada por diversos enunciados a respeito do mundo. A mortalidade, as perdas e separações, o envelhecimento, o desconhecido e a relação com o estrangeiro, com o saber e com a ignorância - todas estas facetas relacionadas à castração estão presentes nos discursos da família e do grupo social.

Estas crenças irracionais aprisionadoras derivam de fantasmas, medos e traumas que permeiam a história familiar, mas que não puderam ser elaborados. Penot entende que as mensagens narcísicas que a história familiar carrega estão 
atravessadas por não ditos, não pensados ou, ainda, por idiossincrasias incompreensíveis. Frequentemente, há experiências de violência que marcam uma família ou grupo social de tal forma que continuam se expressando, mas sem representação. Neste contexto, estas convicções e crenças são formas rígidas de reação ao passado traumático, como se ele ainda estivesse acontecendo. Perante estes conteúdos indigestos, o psiquismo se defende por meio da Recusa, cristalizando-os. Desta forma, não podem ser reinterpretados e abertos à construção de novos sentidos, e, portanto, adquirem o estatuto de verdades absolutas ou crenças imaginárias, que assombram o psiquismo.

O Caso Jeanne, descrito por Penot em Figuras da Recusa (1992), elucida com profundidade este aspecto. Trata-se de uma paciente que acredita que seu genital é diferente do genital de outras mulheres, e é tomada pela compulsão vouyerista de examinar seu corpo. Tal vivência de Unheimliche condensa o estranho-familiar indigesto da condição cultural de seus pais enquanto estrangeiros. No relato de Penot, podemos observar de que modo a herança narcísica de Jeanne é atravessada pelo inconsciente de seus pais e suas próprias dificuldades de elaboração. Delineia-se que a ação da Recusa está ligada a uma transmissão familiar ambígua e contraditória sobre o que significa ser mulher.

Todos herdamos uma bagagem narcísica, mas é preciso contrapô-la a outras experiências, em um movimento dialético que permita a construção de interpretações e ideais próprios. Este movimento envolve representação, elaboração, questionamento e simbolização do que é transmitido, permitindo a transformação de um constructo rígido em um pensamento vivo e dinâmico. Desta forma, mantém-se o vínculo simbólico com a herança familiar, mas há espaço para a criação.

Mas essa travessia pode ser muito custosa, uma vez que, em alguns meios sociais, a contestação de crenças pode levar à exclusão do grupo e ao isolamento. Ao romper com estes fortes ideais prescritos, o sujeito perde a proteção do superego e tem de se defrontar com a ameaça de desamparo afetivo, da desfiliação e da solidão. Este questionamento das crenças requer uma reedição da trama narcísica em que se apoiou para construir o senso de si mesmo. Esta travessia é possível quando se encontra outros olhares e relações em que o sujeito se reconhece, e em que suas percepções e sentimentos são validados. Sem esta sustentação, o sujeito fica órfão.

As crenças intransigentes derivadas da Recusa também derivam de experiências atuais de violência física ou psíquica. A Recusa se instala nestas situações como forma de defender o psiquismo do choque traumático, e cria a ilusão de que nada aconteceu, por meio da não admissão da realidade psíquica, para que não sejam despertados afetos insuportáveis. Ferenczi (1932/2011) descreve que, no momento traumático, a vítima entra em um estado de transe que leva a uma clivagem, como se o sujeito se desligasse de si mesmo para não sentir a dor do momento. 
Nesta situação descrita por Ferenczi, compreendemos que opera a função defensiva da Recusa, ao interromper os processos psíquicos que despertariam afetos insuportáveis. Trata-se de uma tentativa emergencial e desesperada de proteger o psiquismo do impacto emocional imediato. Entretanto, estes elementos que não puderam encontrar ligações psíquicas continuarão como algo tóxico, da ordem do impensável.

Mas a situação se agrava quando há um desmentido. Como proposto por Ferenczi (1932/2011), trata-se do ato de deslegitimar o relato de um evento traumático, por exemplo, quando um adulto diz a uma criança que ela imaginou ou causou o abuso sexual que sofreu. A criança passa a duvidar de suas próprias conclusões sobre o ocorrido e não confia mais em suas próprias percepções. Frequentemente isto ocorre também em situações de violência contra a mulher, em que ela se culpa por ter despertado a ira do companheiro. O desmentido é mais uma forma de desapropriar o sujeito de suas próprias experiências emocionais: ao incorporar o discurso do outro, a vítima internaliza um dogma de uma voz interna que reforça a crença de que foi ela a responsável pelo evento traumático.

É importante destacar que, no momento da violência, a Recusa opera como uma defesa antitraumática, como um anestésico emergencial, mas posteriormente é preciso que a experiência possa ser admitida e processada. No entanto, quando ocorre um desmentido por parte do outro, a ação da Recusa (quanto à não admissão da realidade psíquica) é perpetuada e leva ao adoecimento psíquico. $\mathrm{Na}$ medida em que o desmentido confere irrealidade às representações da experiência traumática, impede a elaboração do trauma. Portanto, concordamos com Ferenczi (1931/2011): o desmentido é que torna o trauma patogênico.

O filme Confiar (Schwimmer, 2010) ilustra muito bem estes aspectos: retrata a reação de uma adolescente ao abuso sexual sofrido. Sua reação inicial é de afirmar que não houve abuso, sentindo-se, de certo modo, lisonjeada por ter tido uma relação sexual com um homem adulto, tal como o agressor lhe fez crer. Como um perverso, o abusador lançou mão de um desmentido que seduz a vítima a consentir com a relação sexual, exercendo sobre ela uma violência psíquica, além da física.

Mesmo quando a família e amigos reconheciam o abuso e a violência, persistia nela a crença de que era uma garota sedutora, o que envaidecia seu narcisismo e a protegia de entrar em contato com as fortes emoções que seriam desencadeadas pelo reconhecimento do trauma. Em busca de certezas confortadoras e asseguradoras, o psiquismo pode ficar imobilizado pelas crenças e tornar-se incapaz de desenvolver um pensamento crítico. É apenas no contato com uma profissional da saúde que a adolescente em questão reconhece que foi abusada. Neste momento, quando o transe e a ação da Recusa são suspensos, a violência do que ela viveu a invade com muita intensidade, mas finalmente ela pôde atribuir sentido à experiência traumática. 
Se por um lado as crenças podem oferecer conforto em momentos de aflição, por outro, a repetição de experiências traumáticas pode gerar uma crença desesperançada. Neste sentido, Figueiredo (2008) aborda a Recusa da utopia em pacientes traumatizados, que se defendem de uma esperança nascente de encontrar um objeto que o ajude na superação e elaboração de traumas. Fechados à alteridade, estes pacientes se blindam do inesperado do futuro, sustentando a crença de que toda nova relação repetirá o fracasso do passado. Deste modo, nutrem esta convicção a fim de se protegerem dos riscos de esperançar por uma vida melhor, temendo reconfortarem-se num colo que poderá deixá-los cair novamente.

Apesar das inúmeras provas da confiabilidade na relação com o analista, o paciente continua esperando ser abandonado ou ferido. Diante de qualquer mínimo sinal de falha do analista, o paciente pensa: "Afinal eu estava certo, não devia ter confiado no meu analista". São crenças à espera de uma confirmação. Este é um dos importantes desafios clínicos envolvendo a Recusa: a duplicidade de realidades psíquicas persistirá em alguma dimensão, apesar do avanço da análise. Afinal, como afirma Freud (1940/2018), a cisão do Eu pode ser remendada, mas não pode ser desfeita.

Por sua vez, Cintra (2004) pondera que, quando as crenças são transformadas, podem gerar maior disponibilidade para a alteridade e para o inesperado, recuperando a esperança no futuro e restaurando a função da utopia. Desde que possam ser revistas e reformuladas a partir das próprias experiências de superação de traumas, as crenças podem nutrir a confiabilidade nos objetos internos e externos para superar as adversidades inerentes ao viver. Isto é o que podemos chamar de fé: recupera-se a confiabilidade do ambiente e a própria capacidade de pedir e receber ajuda; isto pode acontecer de forma independente da fé religiosa.

\section{CONSIDERAÇÕES FINAIS}

A partir de uma perspectiva ampla, que inclui fenômenos cotidianos, mas também aborda formas de adoecimento psíquico, é possível vislumbrar de que modo a Recusa se manifesta em diferentes formas de subjetivação. Por meio da dimensão das crenças, podemos apreender a função defensiva e paradoxal da Recusa. Defensiva porque a crença na mãe fálica, com todas as garantias narcísicas que ela promete, é necessária à constituição psíquica, enquanto não se tem condições de lidar com o pacote da castração. Da mesma forma, a Recusa é protetora quando o psiquismo não tem condições de administrar as intensidades afetivas de experiências traumáticas. Mas este mecanismo de defesa é paradoxal, porque protege o psiquismo às custas de uma cisão do Eu e leva à paralisação dos processos psíquicos.

A persistência da Recusa e das crenças na vida adulta nos revela que as facetas da castração nunca deixam de ameaçar nosso narcisismo e, por vezes, chegam a nos 
imobilizar. Nesse sentido, a relação entre admissão e não admissão da castração pode produzir adoecimentos psíquicos, mas também pode se articular de modo a criar um campo de desejo e esperança. É esta última condição que nos permite seguir investindo na vida, questionando a rigidez de discursos e crenças, e apostando em grandes empreendimentos narcísicos, mesmo sabendo que haverá riscos, perdas e dores inevitáveis.

Então, a relação entre Recusa e crenças nos permite reafirmar a hipótese freudiana de que a Recusa é um mecanismo de defesa presente em todas as formas de subjetivação, e destacar que se trata de um fenômeno muito mais presente na clínica do que se supõe. Portanto, embora ainda seja um conceito pouco difundido entre os psicanalistas, podemos constatar a importância da noção de Recusa para a ampliação da escuta psicanalítica.

\section{REFERÊNCIAS}

Aulagnier, S. P. (2003). A perversão como estrutura. Revista Latinoamericana de Psicopatologia Fundamental, 6, 43-69. doi: 10.1590/1415-47142003003004

Chreim, V. (2019). A infância e o Infantil: sexualidade e gênero. In: Ceccarelli, P. et al. (2019). (Organização). Psicanálise, sexualidade e gênero: um debate em construção. São Paulo: Zagodoni.

Chreim, V. (2019). Dimensões da Recusa: crença, trauma e clínica (Dissertação de mestrado). Pontifícia Universidade Católica de São Paulo, São Paulo.

Cintra, E. M. U. (2004). A questão da crença versus a questão da fé: articulações com a Verleugnung freudiana. Psicologia em Revista, 10, 43-56.

Clavreul, J. (1990). O casal perverso. Em Clavreul, J. et al. O desejo e a perversão. Campinas: Papirus.

Ferenczi, S. (2011). Análises de crianças em adultos. Em Ferenczi, S. Psicanálise IV. São Paulo: Martins Fontes. (Trabalho original publicado em 1931).

Ferenczi, S. (2011). Confusão de línguas entre os adultos e a criança: (a linguagem da ternura e da paixão). In: Ferenczi, S. Psicanálise IV. São Paulo: Martins Fontes. (Trabalho original publicado em 1932).

Ferraz, F. C. (2010). Tempo e ato na perversão. São Paulo: Casa do Psicólogo.

Figueiredo, L. C., \& Coelho Junior, N. E. (2018). Adoecimentos psíquicos e estratégias de cura: matrizes e modelos em psicanálise. São Paulo: Blucher.

Figueiredo, L. C. (2008). Psicanálise: elementos para a clínica contemporânea. São Paulo: Escuta.

Freud, S. (2018). A cisão do Eu no processo de defesa. Em Freud, S. Obras Completas. São Paulo: Companhia das Letras. (Trabalho original publicado em 1940).

Freud, S. (2011). A dissolução do Complexo de Édipo. Em Freud, S. Obras Completas. São Paulo: Companhia das Letras. (Trabalho original publicado em 1924).

Freud, S. (2011). A perda da realidade na neurose e na psicose. Em Freud, S. Obras Completas. São Paulo: Companhia das Letras. (Trabalho original publicado em 1924).

Freud, S. (2011). A negação. Em Freud, S. Obras Completas. São Paulo: Companhia das Letras. (Trabalho original publicado em 1925).

Freud, S. (2011). A organização genital infantil. Em Freud, S. Obras Completas. São Paulo: Companhia das Letras. (Trabalho original publicado em 1923)

Freud, S. (2011). Algumas consequências psíquicas da diferença anatômica entre os sexos. Em Freud, S. Obras Completas. São Paulo: Companhia das Letras. (Trabalho original publicado em 1925).

Freud, S. (2015). Análise da fobia de um garoto de cinco anos ("O pequeno Hans"). Em Freud, S. Obras Completas. São Paulo: Companhia das Letras. (Trabalho original publicado em 1909).

Freud, S. (2018). Compêndio de psicanálise. Em Freud, S. Obras Completas. São Paulo: Companhia das Letras. (Trabalho original publicado em 1940). 
Freud, S. (2014). Conferências introdutórias à psicanálise. Em Freud, S. Obras Completas. São Paulo: Companhia das Letras. (Trabalho original publicado em 1916-1917).

Freud, S. (2010). Introdução ao narcisismo. Em Freud, S. Obras Completas. São Paulo: Companhia das Letras. (Trabalho original publicado em 1914).

Freud, S. (2011). Neurose e psicose. Em Freud, S. Obras Completas. São Paulo: Companhia das Letras. (Trabalho original publicado em 1924).

Freud, S. (2011). O Eu e o Id. Em Freud, S. Obras Completas. São Paulo: Companhia das Letras. (Trabalho original publicado em 1923).

Freud, S. (2014). O fetichismo. Em Freud, S. Obras Completas. São Paulo: Companhia das Letras. (Trabalho original publicado em 1927).

Freud, S. (2010). O inquietante. Em Freud, S. Obras Completas. São Paulo: Companhia das Letras. (Trabalho original publicado em 1919).

Freud, S. (2011). O problema econômico do masoquismo. Em Freud, S. Obras Completas. São Paulo: Companhia das Letras. (Trabalho original publicado em 1924).

Freud, S. (2006). Observações adicionais sobre as neuropsicoses de defesa. Em Freud, S. Edição Standard Brasileira das Obras Psicológicas Completas de Sigmund Freud. Rio de Janeiro: Imago. (Trabalho original publicado em 1986).

Freud, S. (2015). Sobre as teorias sexuais infantis. Em Freud, S. Obras Completas. São Paulo: Companhia das Letras. (Trabalho original publicado em 1908).

Laplanche, J., \& Pontalis, J. B. (2001). Vocabulário da psicanálise. São Paulo: Martins Fontes.

Mannoni, O. (1991). Eu sei, mas mesmo assim. Em Katz, C.M. (org). Psicose. São Paulo: Escuta (Trabalho original publicado em 1969).

Penot, B. (1992). Figuras da Recusa: aquém do negativo. Porto Alegre: Artes Médicas.

Pinheiro, T. (1999). Em busca de uma metapsicologia da melancolia. Em Birman, J. (org.) Sobre a psicose. Rio de Janeiro: Contra Capa.

Schwimmer, D. (Direção). (2010). Trust [Confiar] [Filme]. Millennium Films.

Winnicott, D. W. (1975). Objetos transicionais e fenômenos transicionais. Em Winnicott, D. W. O brincar e a realidade. Rio de Janeiro: Imago. (Trabalho original publicado em 1971).

\section{AGRADECIMENTOS}

Agradecemos a Fernanda Fazzio, Aline Choueke Turnowski, Eduardo Zaidan e Luis Claudio Figueiredo pela leitura atenta.

\section{CONFLITOS DE INTERESSES}

Não há conflitos de interesses.

\section{FINANCIAMENTO}

Conselho Nacional de Desenvolvimento Científico e Tecnológico (CNPq).

\section{SOBRE OS AUTORES}

Vanessa Chreim é psicóloga e psicanalista, Mestre em Psicologia Clínica pela PUC-SP, membro efetivo do Departamento Formação em Psicanálise do Instituto Sedes Sapientiae.

E-mail: vachreim@hotmail.com

(iD) https://orcid.org/0000-0001-5906-0233 
Elisa Maria de Ulhôa Cintra é psicanalista, professora da faculdade de Ciências Humanas e da Saúde da PUC-SP e do Programa Pós em Psicologia Clínica da PUC-SP. Coordenadora (com a Profa. Marina Ribeiro) do Laboratório Interinstitucional de Estudos da Intersubjetividade e da Psicanálise Contemporânea - LIPSIC - IPUSP/PUC-SP. Membro do GT Clínica Ampliada. Autora de Melanie Klein: estilo e pensamento e A Folha Explica Melanie Klein (em coautoria com L.C. Figueiredo). Organizadora (com G. Tamburrino e M. Ribeiro) e autora de capítulo do livro de Para Além da Contratransferência - o analista implicado e do livro Por que Klein? (em coautoria com Marina Ribeiro).

E-mail: elcintra01@gmail.com

(iD) https://orcid.org/0000-0003-2362-1136

\footnotetext{
1 É o que observamos no caso do menino do cordão, paciente descrito por Winnicott no primeiro capítulo de $O$ brincar e a realidade (1971/1975), em que a brincadeira do paciente passa a adotar as características do fetichismo, abandonando a qualidade transicional do uso do cordão, como forma de negação da separação dele com sua mãe.

${ }^{2}$ Esta concepção contemporânea contribui para as reflexões acerca das questões de gênero, no sentido da despatologização da transexualidade, tema desenvolvido no texto $A$ infância e o Infantil: sexualidade e gênero (Chreim, 2019).

${ }^{3}$ Segundo Paulo César de Souza, o termo Aüflosung pode ser traduzido como "dissolver" ou "desintegrar", enquanto o termo Untergang, presente no título do texto A dissolução do Complexo de Édipo (Freud, 1924/2011), pode significar ruína, naufrágio, ocaso, poente (pôr-do-sol), destruição.
} 